\title{
Soldiers, parties and bureaucrats: illicit fund-raising in contemporary Indonesia
}

\author{
Marcus Mietzner
}

\begin{abstract}
This article discusses illicit fund-raising efforts in Indonesia's armed forces, political parties and bureaucracy after the fall of Suharto in 1998. It argues that while personal self-enrichment remains a key motivation for military leaders, party politicians and bureaucrats to collect off-budget funds, there are also other crucial factors. Most importantly, all three sectors aim to control independent funds in order to maintain or strengthen their autonomy from other state institutions, such as parliamentary budget commissions, executive monitoring bodies or official auditing boards. By engaging in extensive self-financing practices, however, the three political actors undermine their own professionalism, functional effectiveness and internal coherence, and obstruct Indonesia's process of democratic consolidation.
\end{abstract}

Keywords: military; bureaucracy; parties; corruption; democracy; Indonesia

One of the most important preconditions for successful democratic transitions is the ability of the state to introduce transparent funding mechanisms for its key political actors. In authoritarian or illiberal regimes, crucial institutions such as the military, political parties and the bureaucracy are often dependent on financial patronage dispensed by the all-powerful ruler, or are encouraged to raise their own funds through intimidation, extortion or corruption. After the fall of the autocracy, reforming the financial management of these critical state agencies and political groups typically emerges as an urgent policy priority. The reason for this is as simple as it is compelling: if allowed to continue their unaccountable financing practices, all three sociopolitical players could seriously undermine the democratic transition. The military, for example, could not only launch independent challenges to the transitional government, but also engineer security 
disturbances that make it impossible for the new polity to stabilize. Political parties, which are often the main vehicles of change in transitional states, could turn into corrupt electoral machines for old elites and therefore fail to carry out their function of political aggregation and representation. Finally, the bureaucracy - the indispensable tool for any government to implement its policies - could sabotage the reform process by delaying, obstructing or ignoring the reform agenda defined by the executive.

In post-Suharto Indonesia, the need to reform the financing system of the armed forces, the parties and the bureaucracy was of particular urgency. To begin with, the military had since its inception in the 1940s raised substantial parts of its funds from off-budget sources. Keen to avoid oversight by civilian control agencies, the armed forces, or TNI [Tentara Nasional Indonesia, Indonesian National Military] had set up a financing network that allowed them to allocate and spend much of their money independently from the state. The political parties, on the other hand, had been institutionally weakened by 40 years of authoritarian rule, making them vulnerable to external pressure, economic interests and corruption. In addition, the decision of President Habibie in June 1998 to lift all restrictions immediately on the establishment of parties caught many political actors off guard, forcing them to raise funds quickly to create their own parties. The bureaucracy, for its part, had a long tradition of financing itself through huge numbers of offbudget accounts, filled with monies derived from political patrons, entrepreneurs and corrupt practices. In short, the deeply entrenched habit of illicit fund-raising in the military, the parties and the bureaucracy posed a serious challenge to Indonesia's post-authoritarian governments, with each of these three actors playing an important role in determining the success or failure of the democratic transition.

This article discusses the ongoing practice of illicit fund-raising in some of Indonesia's key political and security institutions since Suharto's fall in 1998. It evaluates the extent to which the financing methods institutionalized under the New Order and previous polities have survived the 1998 regime change, and highlights new funding patterns that only emerged under the democratic system. In three separate sections, I analyse the fund-raising mechanism of the armed forces, the political parties and the bureaucracy. In each section, the article provides a short historical overview of the funding practices prevalent under the regimes before 1998, before discussing the most recent patterns and trends. In the conclusion, I evaluate the repercussions of illicit 
fund-raising for the effectiveness, functionality and internal coherence of the three sectors on the one hand, and for the prospects of Indonesia's democratic consolidation on the other. Emphasizing that the military, the parties and the bureaucracy try to defend their financial autarchy in order to escape political scrutiny and accountability, I argue that unless Indonesia undertakes credible efforts to establish more effective funding mechanisms for some of its most important political agencies and groups, its democratic system will continue to be marred by serious institutional defects.

\section{The military: from guerrilla war to financial autonomy}

In the academic debate on military financing, authors have generally agreed that the dependence of militaries on informally raised monies impacts negatively on both the quality of democracy and the professionalism of the armed forces. As Brömmelhörster and Paes explained, 'the existence of off-budgetary sources of revenue makes armed forces more independent and less accountable to civilian governments'. ${ }^{1}$ States that do not cover all expenses of their militaries typically find it difficult to control them, and the effectiveness of democratic governance declines as a result. Financially independent militaries can grow into powerful veto players, with the potential to undermine democratic reforms and preserve military privileges that are incompatible with open and transparent societies. The other negative impact of military selffinancing relates to the combat-readiness and professionalism of the armed forces. Military officers whose primary task it is to raise funds have little time and opportunity to develop their professional skills, and they often completely lose interest in their defence mission because illicit economic activities promise a faster avenue to personal wealth than a combat-oriented military career. Overall, self-funded armed forces are much more likely to become 'political armies' than those that depend on allocations from the state. ${ }^{2}$

The Indonesian military has a long history of raising its own funds. Founded in 1945 to confront the returning Dutch colonial army, TNI

1 Jörn Brömmelhörster and Wolf-Christian Paes (2003), 'Soldiers in business: an introduction', in The Military as an Economic Actor: Soldiers in Business, Palgrave Macmillan, Basingstoke and New York, p 16.

2 Kees Koonings and Dirk Kruit (2002), Political Armies: The Military and Nation Building in the Age of Democracy, edited volume, Zed Books, London and New York. 
initially consisted of a large network of independent militias. These militias were controlled and funded by local commanders and societal leaders, who in turn raised money from the population of the area in which they operated. Subsequently, the civilian government put a lot of effort into centralizing the command structure and strengthening its control over the military budget, and by early 1947 it had temporarily succeeded. Supervised by the Defence Ministry, a special 'Bureau of Struggle' [Biro Perjuangan] was put in charge of coordinating the activities of the military's various units and their expenditure. ${ }^{3}$ However, after the Dutch intensified their attacks in mid-1947 and throughout 1948, the government not only lost control over much of its claimed territory, but also over its military commands. As a consequence, A.H. Nasution, one of the key generals in the army, declared in December 1948 that a military government had been established for Java, with officers assuming authority over civilian administrations at the local level. ${ }^{4}$ One important aspect of this assumption of administrative control was that it gave the military direct authority to raise funds and collect taxes. For example, in March 1949 the military governor of West Central Java issued a decree that required paddy field owners to pay $10 \%$ of the value of their harvest as 'rent' to the government, and an additional 10\% income tax was levied on all other citizens. ${ }^{5}$ The autonomy of military commanders in fund-raising and financial management went so far that one TNI leader even proposed to print his own currency to finance the operations in his area. ${ }^{6}$

After the end of the war in 1949, the Indonesian government moved to increase its political and financial control of the military. Consequently, the armed forces became more dependent on allocations from the official state budget, leading to widespread dissatisfaction in the officer corps. This discontent was aggravated by the fact that many Indonesian politicians tried to keep the budget of the armed forces as small as possible, partly because of genuine financial constraints, but also because they feared that an institutionally powerful military could turn against the newly established parliamentary democracy. When

Salim Said (1992), Genesis of Power: General Sudirman and the Indonesian Military in Politics, Institute of Southeast Asian Studies, Singapore and Pustaka Sinar Harapan, Jakarta, p 44. As a result of this centralization programme, the military received most of its funds through the state budget. At the height of the conflict with the Dutch, around $80 \%$ of the government's budget went into the war effort. I am grateful to Robert Cribb for providing this information.

Ian MacFarling (1996), The Dual Function of the Indonesian Armed Forces: Military Politics in Indonesia, Australian Defence Studies Centre, Canberra, p 41.

Said, supra note 3, at pp 107-108.

MacFarling, supra note 4, at p 42. 
the army leadership unsuccessfully demanded the dissolution of parliament in 1952, the civilian elite cut the allocations for TNI even further. Frustrated with TNI's dependence on the monies granted by civilian leaders, Nasution in 1957 and 1958 ordered the institutionalization of the military's territorial command structure. This network of military units reached from the centre down to the village level, and ran parallel to the civilian bureaucracy. Most importantly, each unit was tasked with setting up independent businesses and cooperatives that could help with the financing of military operations. The regional rebellions in the late 1950 s, which led to the declaration of martial law, accelerated this economic engagement of the military and consolidated its financial autonomy. ${ }^{7}$ In addition, the nationalization of Dutch enterprises in December 1957 entrenched military officers in the management of large corporations, paving the way for TNI to become a major economic player. Accordingly, when the army under Major-General Suharto took power in October 1965, the foundations for the military's economic strength had already been laid.

The New Order period (1965-98) witnessed a massive expansion of military businesses, cooperatives and foundations. The military's central position in the regime provided its officers, according to Richard Robison, with 'almost unlimited access to the resources and facilities of the state and power to influence allocation of import/export licenses, forestry concessions and state contracts' ${ }^{8}$ In fact, the political weight of the armed forces was so overwhelming that they were not only able to run a large complex of military businesses, but established effective control over key state enterprises as well. For example, one of the major cash cows of the armed forces was the national oil company Pertamina, which delivered substantial contributions to the budget of the armed forces and their military directors. ${ }^{9}$ In addition to the military's direct economic involvement, regional commanders also forged business alliances with local entrepreneurs, offering a service that Robert Lowry called 'facilitation'. ${ }^{10}$ Besides obtaining business licences, this

Harold Crouch (1988), The Army and Politics in Indonesia, Cornell University Press, Ithaca and London, p 38.

8 Richard Robison (1986), Indonesia: The Rise of Capital, Asian Studies Association of Australia, Sydney, p 252.

9 Iswandi (1998), Bisnis Militer Orde Baru: Keterlibatan ABRI dalam Bidang Ekonomi dan Pengaruhnya Terhadap Pembentukan Rezim Otoriter, Remaja Rosdakarya, Bandung, pp 146-151.

10 Robert Lowry (1996), The Armed Forces of Indonesia, Allen \& Unwin, St Leonards, p 141. 
covered assistance 'in resolving land disputes, calming labour unrest, overcoming bureaucratic obstacles, relocating squatters, and so on'. The business elite, Lowry concluded, found it 'prudent to keep the local military on side against the day when social unrest might threaten their lives and property'. Finally, Suharto ensured that the armed forces were also financed through (and therefore dependent on) regular payments made by both his own foundations and the companies of his cronies, who were mostly ethnic Chinese entrepreneurs.

\section{Military businesses after 1998}

The character of military fund-raising changed significantly after Suharto's fall in 1998. Most importantly, the large military conglomerates, which had profited from three decades of economic growth and protection under the New Order, suffered enormous losses during the financial crisis of 1997 and 1998. Many of TNI's assets were wiped out, as were the companies of its main sponsors. Independent audits of some of the military's key foundations in 2000 and 2001 found that many of the military-affiliated companies were technically bankrupt, with only a small minority of business units still generating profits. ${ }^{11}$ In the same vein, previously affluent military cronies such as Liem Sioe Liong or Eka Cipta Wijaya suffered under huge debts, and some of them relocated to Singapore or Hong Kong in order to escape their financial and legal obligations. For that reason, they were no longer available as funding sources for the armed forces and individual generals. An equally crucial element in the military's economic woes was the decline of its political significance. With TNI no longer the decisive force in Indonesian politics, patronage-seeking investors increasingly turned to new actors in the post-authoritarian polity: political parties, parliamentarians, bureaucrats and influential socio-religious leaders. ${ }^{12}$ The collapse of its largest enterprises, the loss of its key donors and the decreasing power of its political patronage forced the military to alter the pattern of its fund-raising efforts substantially.

One of the most important consequences of the erosion of TNI's institutional businesses was a significant increase in its 'informal' economic activities. In order to compensate for the reduced revenue from formal

11 Ernst \& Young (2001), 'Yayasan Kartika Eka Paksi: Strategic Review Report Phase II', Ernst \& Young, Jakarta.

12 Marcus Mietzner (2006), The Politics of Military Reform in Post-Suharto Indonesia: Elite Conflict, Nationalism, and Institutional Resistance, Policy Studies 23, East-West Center, Washington, DC. 
businesses, military officers and their soldiers intensified their engagement in a wide variety of semi-legal and illicit enterprises. The most common of these activities was providing security for businesses, ranging from large multinational corporations to small companies at the local level. In these deals, local commanders would order their soldiers to protect the business premises of an entrepreneur or investor in exchange for food supply, equipment and cash. These payments could be as high as US\$6 million a year, as in the case of Freeport McMoRan's gold and copper mine in Papua, ${ }^{13}$ or as low as US\$100 from a Chinese shop owner in a small town or village. While such security services were in open violation of existing laws and regulations - which do not allow the military and the police to receive money from external donors - the government has openly tolerated this practice. In recent years, the Ministry of Defence has announced on several occasions that it would issue and enforce new guidelines on the security offered to so-called 'vital objects' (that is, large businesses for which the government feels obliged to provide protection). Despite these pledges, however, there appears to have been no change in the pattern of external funding for the military and police by the owners of these sites.

Other questionable or semi-illegal business activities included the renting out of military property to private investors. This practice often took the form of contracts between commanders and entrepreneurs, through which military-owned land was leased to business people for a certain period of time. In Jakarta, the French supermarket giant Carrefour built one of its retail branches on a piece of land provided by the armed forces, and similar deals were made throughout the archipelago. Most significantly, these contracts were not only questionable in legal terms, but also led to frequent conflicts with the local population. In one such case that occurred in May 2007, marine soldiers killed four villagers in Pasuruan in East Java after they had protested against TNI's leasing of a plot of land to a private company (PT Rajawali Nusantara), even though the land title for the property concerned was still disputed between the military and the local community. ${ }^{14}$ In addition to these shadowy leasing contracts, officers and their troops engaged in outright illegal activities. They backed up prostitution, gambling and other

13 Human Rights Watch (2006), Too High a Price: The Human Rights Cost of the Indonesian Military's Economic Activities, Human Rights Watch, New York, pp 48-56. The report's figures for Freeport payments to TNI and police forces are based on the company's own filings under US transparency requirements.

14 '4 Warga Tewas Ditembak Marinir', Kompas, 31 May 2007. 
entertainment venues, assisted criminal operators in illegal logging, mining and fishing, moonlighted as debt collectors, drug couriers and even assassins, and frequently sold their weapons, explosives and equipment. ${ }^{15}$ While such criminal acts could be observed across Indonesia, they were particularly prevalent in conflict or post-conflict areas such as Maluku, Central Sulawesi, Aceh and Papua. There, unstable security conditions and weak law enforcement created ample opportunities for rent-seeking military elements to run their illegal operations, and conflicting parties would typically offer money to soldiers to take their sides or sell them TNI-owned arms.

Besides increasing their informal business activities, the armed forces also tried to offset the decline of their large enterprises by maintaining and expanding TNI's network of small cooperatives attached to the territorial command structure. Consequently, after 1998 the majority of military leaders fiercely opposed any attempt by civilian governments or reform-oriented officers to revamp the territorial system. In 2000, reformist officers around the outspoken general Agus Wirahadikusumah demanded the gradual disbandment of the structure, but their efforts were undercut by the conservative TNI mainstream. The anti-reform generals eventually succeeded in sidelining Wirahadikusumah, and the reform project was aborted. In 2001, another reformist general, Agus Widjojo, tried to launch a more moderate plan for reforming the territorial units, but like Wirahadikusumah, he was quickly marginalized and his ideas were shelved. ${ }^{16}$ Since then, no further attempt at reforming the system has been undertaken. The defensive attitude of the military was hardly surprising. The territorial command structure not only anchored the military deeply in local politics, but also allowed it to raise funds at all levels of Indonesia's civilian administration. Thus after the breakdown of TNI's large businesses in 1997 and 1998, the financial autonomy of the armed forces rested to a large extent on the vast network of small enterprises and cooperatives throughout the country. Had the territorial system been disbanded or substantially reformed, the military would have gradually lost its institutional autarchy.

Tabloids and crime programmes on television continue to be filled with stories about soldiers being arrested for a wide variety of illegal activities. Military units also often stage public dismissal ceremonies for soldiers who have been caught committing crimes, most of which are connected to illegal fund-raising. While military commands tend to tolerate and even encourage the moonlighting of their soldiers, they do not want to see these practices exposed in the media - hence the stern action taken. '192 Prajurit Kodam I Bukit Barisan Diepecat', Kompas, 5 July 2007. 
This critical importance of the territorial business units for TNI was demonstrated eloquently in 2005, when the government initiated a halfhearted attempt to bring them under state control.

\section{The government's takeover plans after 2004}

For much of Indonesia's democratic transition, the political elite did not view the problem of TNI's businesses and self-financing practices as an urgent policy issue. The armed forces had raised large proportions of their funds from off-budget sources since the birth of the Indonesian Republic, making it difficult for the government and the legislature to imagine - let alone enforce - alternative means of military financing. In addition, the Indonesian state was still recovering from the economic crisis of 1997 and 1998, and it consequently faced a myriad of investment needs in other fields, such as infrastructure and the health, education and agriculture sectors. It was only in 2004 that a small group of parliamentarians from a variety of parties deemed it necessary to put the topic of military financing on the political agenda. This alliance of legislators used the deliberations on the TNI Act, which took place in parliament shortly before President Megawati Sukarnoputri left office in October 2004, to insert a clause in the new bill that required the government to take over all military businesses by 2009. In order to close all possible loopholes for the armed forces, the parliament clarified that all businesses, whether 'directly or indirectly' owned by the military, should be included in the planned transfer. ${ }^{17}$

Although not enthusiastic about this assignment, Minister of Defence Juwono Sudarsono pledged to fulfil parliament's request. He asked TNI to draft a list of all its enterprises and hand it over to his department. When TNI Commander Endriartono Sutarto submitted the list in September 2005, there was significant confusion about the number of businesses that TNI admitted owning. The military's initial inventory featured a total of 219 businesses, cooperatives and foundations, but this grew to 1,520 in April 2006. In September 2007, a senior government bureaucrat in charge of the inventory updated the figures once again, mentioning 25 foundations, 1,071 cooperatives and 1,520 businesses units, making a total of 2,616 military-owned enterprises (Table 1).

Even more confusing than the constantly rising number of businesses

17 Article 76 of the bill stated that 'within 5 years after the enactment of this law, the government has to take over all business enterprises owned or operated by TNI in a direct or indirect manner'. See 'Undang-Undang Republik Indonesia Nomor 34 Tahun 2004 Tentang Tentara Nasional Indonesia'. 
Table 1. Inventory of TNI businesses (September 2007).

Foundations

Business units

Cooperatives

Total

\section{5}

1,520

1,071

2,616

Source: Said Didu, chairman of the government's team for the transfer of military businesses, quoted in Pelita, 28 September 2007.

was the subsequent debate over which of them qualified for handover to the state. The military argued that cooperatives and foundations did not constitute 'businesses', obviously trying to exploit shortcomings in the TNI Act, which made no mention of these forms of enterprises. Simultaneously, TNI leaders also insisted that cooperatives and foundations were still necessary for the welfare of the troops. ${ }^{18}$ This questionable redefinition of the term 'business' excluded, with the strike of a pen, a huge portion of TNI's assets from the handover project. Furthermore, the generals submitted that only military businesses that contained 'state assets' should be handed over to the state. While the logic of this argument was not immediately obvious - as a state institution, the military should consider all its possessions as state assets - it created additional irritation on the part of the government. ${ }^{19}$ It quickly emerged that the Department of Defence and other civilian agencies had not prepared their own conceptual parameters for the planned takeover, allowing the military to gain a significant advantage in the discussion. Eventually, the government supported the military's interpretation of the term 'business', and it allowed the armed forces to announce that only 'six or seven' businesses would be taken over by the state. ${ }^{20}$ As a result, the government no longer talked about assuming control over cooperatives and foundations, but instead promoted their 'purification', stating vaguely in October 2007 that they should 'turn into "pure" cooperatives and foundations' by $2009 .{ }^{21}$ While the government expressed its hope that the cooperatives and foundations should no longer be 'glued' to TNI, it did not explicitly

In his confirmation hearing in parliament, TNI Commander Djoko Santoso stated in December 2007 that 'the cooperatives in TNI will continue to be developed, with a special focus on fulfilling the basic needs of soldiers and their families'. See Jenderal TNI Djoko Santoso (2007), Paparan Pada Rapat Kepatutan dan Kelayakan [Fit and Proper Test] Calon Panglima TNI, 5 December, Jakarta, p 33.

19 'Verifikasi Bisnis TNI Selesai Januari 2006', Kompas, 29 November 2005.

20 'Erry Riyana Akan Pimpin Tim Pengalihan Bisnis TNI', Koran Tempo, 19 November 2007.

21 'Aktivitas Bisnis TNI Segera Dilaporkan ke Presiden', Pelita, 28 September 2007. 
rule out the possibility that the military would remain in charge of their management.

Beyond the confusion over its terms and definitions, the takeover plan was also undermined by uncertainty over the technicalities and the legal framework for the ownership transfer. After TNI had submitted its inventory list, the government set up a Supervisory Team for the Transformation of TNI Businesses [Tim Supervisi Transformasi Bisnis TNI, TSTB]. The task of that team was to verify the inventory and produce a draft for a presidential decree that would regulate the details of the handover. The draft decree was submitted to President Susilo Bambang Yudhoyono in 2006, but apparently the government was in no rush to sign it. In February 2007, Yudhoyono returned the draft for revisions, without giving indications as to what kind of changes he would like to make. ${ }^{22}$ As a consequence of the delays and the ensuing legal vacuum, TNI was able to sell off some of its more profitable assets before the government could take them over. Among these assets were TNI's share in the Artha Graha Bank, which was widely viewed as the main investment arm of the military, and the airline Mandala. ${ }^{23}$ As their sale fell into a transitional period, the Department of Defence declared that the transactions were legal and that the state could not claim the proceeds. Many observers suspected, however, that the armed forces simply sold these prime assets to their civilian cronies, and in fact remained in control of these cash cows. ${ }^{24}$

The most consequential defect in the government's takeover project, however, was its failure to address the problem of TNI's informal businesses. According to the TSTB, the value of all formal military businesses was not more than 1 trillion Rupiah (US\$111 million). ${ }^{25}$ Interestingly, this is the figure for the alleged total net worth of the assets, not the yearly revenues. Based on the estimate of their capital value, the annual income generated by these businesses is unlikely to reach more than US\$10 to 20 million (which is, coincidentally, close to the amount that academics Lex Rieffel and Jaleswari Pramodhawardani have come

22 The best documentation on Yudhoyono's rejection of the draft was presented on the Internet news portal, detik.com. It covered this event for several days: 'SBY Minta Draf Produk Transformasi TNI Diperbaiki' (9 February 2007); 'Dephan Siap Revisi Perpres Transformasi Bisnis TNI' (13 February 2007); 'Harmonisasi Institusi Pengambil Alih Bisnis TNI' (13 February 2007). The decree was eventually signed in April 2008.

23 'Penjualan Saham TNI di Artha Graha Disorot', Bali Post, 8 September 2005.

24 Confidential interview with an observer of military affairs, Jakarta, November 2007.

25 Interview with Effendi Choirie, member of parliament's Commission I on defence and security, Jakarta, 5 December 2007. 


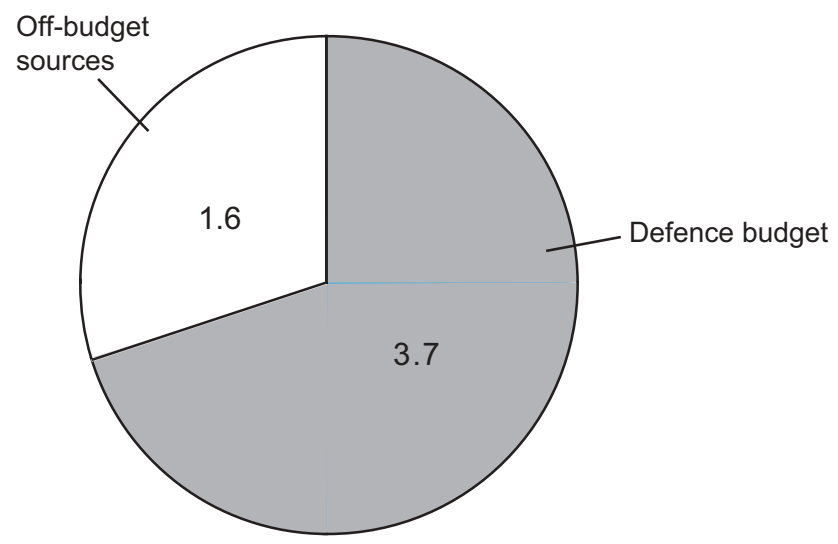

Figure 1. Indonesia's defence budget and off-budget funds, 2007/08 (billion US\$). Source: Based on an estimate by Juwono Sudarsono, Minister of Defence, that $30 \%$ of the military's total expenditure was covered by off-budget sources; interview with the author, 1 May 2007, Jakarta.

up with in their study on the topic). ${ }^{26}$ This, in turn, would mean that the revenues of the institutional military businesses make up only $0.5 \%$ of the whole defence budget, which stood at around US\$3.7 billion in the fiscal year 2008. However, even Minister of Defence Juwono Sudarsono believes that circa $30 \%$ of the military's expenditure is still raised from off-budget sources. Using Juwono's estimate as a guideline, the total value of all off-budget funds in TNI's expenditure for 2008 would be around US\$1.6 billion (see Figure 1). This shows that the government's effort to take over the military's formal businesses would capture only around $1.3 \%$ of TNI's business activities, leaving more than $98 \%$ of its off-budget sources - mainly derived from informal enterprises - untouched.

The unwillingness of the military to relinquish its cooperatives and foundations, and the reluctance of the government to regulate TNI's informal business activities, pointed to the continued importance of these off-budget sources for the institutional autonomy of the armed forces. Apparently, the military was not prepared to rely exclusively on state allocations to fund its operational activities - despite the fact that the defence budget had seen significant increases since Suharto's

26 Lex Rieffel and Jaleswari Pramodhawardani (2007), Out of Business and On Budget: The Challenge of Military Financing in Indonesia, Brookings Institution Press and US Indonesian Society, Washington, DC. 
fall. Between 2004 and 2008 alone, the state budget for the armed forces increased by $73 \%$, leading to changes in the balance between the military's on-budget and off-budget funds. ${ }^{27}$ Before 2004, it was commonly estimated that $70 \%$ of the military's expenditure was raised outside of the state budget. This share declined to around $30 \%$ in 2008, while the total value of the off-budget revenues arguably remained stable at around US $\$ 1.6$ billion. In other words, while the government has increased the portion of its funding for the military, the net worth of the informal income of the armed forces has not changed. Given these continuously high levels of illicit budgeting, the efforts of the government to assume control over a small number of military enterprises are unlikely to alter substantially the pattern of self-funding within the armed forces. Consequently, bringing the military completely on budget will continue to be one of the biggest political challenges for the Jakarta government. As long as the armed forces are able to raise considerable percentages of their expenditure from non-state sources, Indonesia's consolidating democracy will remain vulnerable to the military's inherent drive for political interference, ideological hegemony and independent security operations.

\section{Political parties: state subsidies, donations and political corruption}

In the current scholarly discussion of party financing, the provision of state subsidies is generally viewed as the most practical way to fund parties in contemporary democracies. While the ideal model is that of a mass party funded through membership fees and internal contributions,$^{28}$ this type of party organization has become increasingly rare. Modern parties are now mostly elite-based electoral parties, which run high-cost media campaigns and need to hire external consultants to manage some of their operations. As a result of this decline of the mass parties in the 1980s and 1990s, public party financing was introduced around the globe. In $75 \%$ of all liberal democracies in the world, the state provides financial assistance to its political parties, with no significant differences between old and new democracies. ${ }^{29}$ India, Switzerland,

27 'Menteri Juwono: Anggaran Pertahanan 2008 Tak Dipotong', Koran Tempo, 18 August 2007.

28 Richard Katz (1997), Democracy and Elections, Oxford University Press, Oxford.

29 Ingrid Biezen and Petr Kopecky (2007), 'The state and the parties: public funding, public regulation and rent-seeking in contemporary democracies', Party Politics, Vol 13, No 2, pp 235-254. 
New Zealand and the USA are the only large liberal democracies that do not allocate public funds to political parties, but even in some of these countries, public financing is available for individual candidates. The region with the lowest level of state financing for parties is Africa, with only $44 \%$ of the democracies there offering public funds to political parties. Thus it appears that the more consolidated a multi-party democracy, the more likely it is to view public party funding as the most suitable option to maintain the independence and professionalism of its political parties.

In Indonesia, there was no strong tradition of public party financing before Suharto's fall in 1998. During the parliamentary democracy of the 1950s, for example, no state subsidies were provided to party leaderships. Instead, parties typically tried to place some of their functionaries in key positions of the state bureaucracy, expecting them to channel monies from their departments into the party coffers. Among the dominant parties, the PNI [Partai Nasionalis Indonesia, Nationalist Party of Indonesia] enjoyed the highest levels of entrenchment in the bureaucracy, but others had significant access as well. NU [Nahdlatul Ulama, Awakening of the Islamic Scholars], for instance, relied on the Department of Religious Affairs to provide money, jobs and facilities to its members and supporters. ${ }^{30}$ By contrast, the authoritarian New Order exercised tight control over its political parties, and Suharto made sure that they became financially dependent on him. The only two non-government parties allowed to operate - the secular-nationalist PDI [Partai Demokrasi Indonesia, Indonesian Democratic Party] and the Islamic PPP [Partai Persatuan Pembangunan, United Development Party] - were provided with offices and monthly maintenance payments, ensuring that they remained institutionally tied to the regime. However, these allowances were sufficiently small to prevent PDI and PPP from growing into credible challengers to the government. The New Order's electoral machine Golkar, on the other hand, was equipped with a large trust fund, the payments from which were approved by Suharto himself. ${ }^{31}$ Moreover, government departments were expected to help Golkar financially and politically. In short, while a certain kind of public party financing existed under Suharto, this was not intended to create a level playing field for all participants, but to secure their loyalty to the autocrat.

30 Greg Fealy (1998), 'Ulama and politics in Indonesia: a history of Nahdlatul Ulama, 1952-1967', PhD dissertation, Department of History, Monash University, Melbourne.

31 Interview with Akbar Tandjung, former general chairman of Golkar, 17 December 2006, Jakarta. 


\section{Party revenues and expenditures after 1998}

After Suharto's resignation, Indonesia's elite agreed that the newly emerging political parties needed to receive regular subsidies from the state if they were expected to participate effectively in the democratic system. Before 2001, these subsidies were paid in an irregular and sporadic manner, with the government extending some assistance during the 1999 elections..$^{32}$ In 2001, however, President Wahid issued a decree that granted all parties regular subsidies, the amount of which was determined by their performance in the 1999 ballot. Each central party board was to obtain 1,000 Rupiah (US\$0.11) per vote, and provincial and district-level governments were encouraged to pay an equivalent sum to the party branches in their regions. These subsidies were significant contributions to the parties' treasuries. Megawati Sukarnoputri's PDI-P [Partai Demokrasi Indonesia Perjuangan, Indonesian Democratic Party of Struggle], for example, would receive 35.7 billion Rupiah (around US\$3.9 million) each year for its central office. In addition, given that most local administrations followed the payment formula used by the central government, PDI-P's 32 provincial and 440-plus district boards presumably obtained another 70 billion Rupiah (US $\$ 7.7$ million). Accordingly, PDI-P is likely to have collected a total of around 422.8 billion Rupiah (US\$47 million) between 2001 and 2004 in official state funding alone. ${ }^{33}$

In 2005, however, the freshly installed government under Susilo Bambang Yudhoyono issued a new decree on public party financing that led to a dramatic drop in party revenues. The government never explained the reasons for its decision, but it is clear that some influential bureaucrats had been unhappy about what they viewed as undeserved financial assistance to increasingly unpopular political parties. Based on the new decree, the funding formula for political parties was changed from 1,000 Rupiah per vote to 21 million Rupiah per seat obtained in the 2004 elections. As a result, PDI-P's annual state subsidies dropped from 35.7 billion to just 2.3 billion Rupiah. Altogether, the total subsidies to political parties declined from 105 billion to 11.5 billion Rupiah, a drop of $89 \% .{ }^{34}$ Most importantly, this sharp slump in official party

32 Marcus Mietzner (2007), 'Party financing in post-Soeharto Indonesia: between state subsidies and political corruption', Contemporary Southeast Asia, Vol 29, No 2, p 242.

33 These calculations are based on PDI-P's election result in 1999, with 1,000 Rupiah paid per vote.

34 Mietzner, supra note 32, at p 244. 


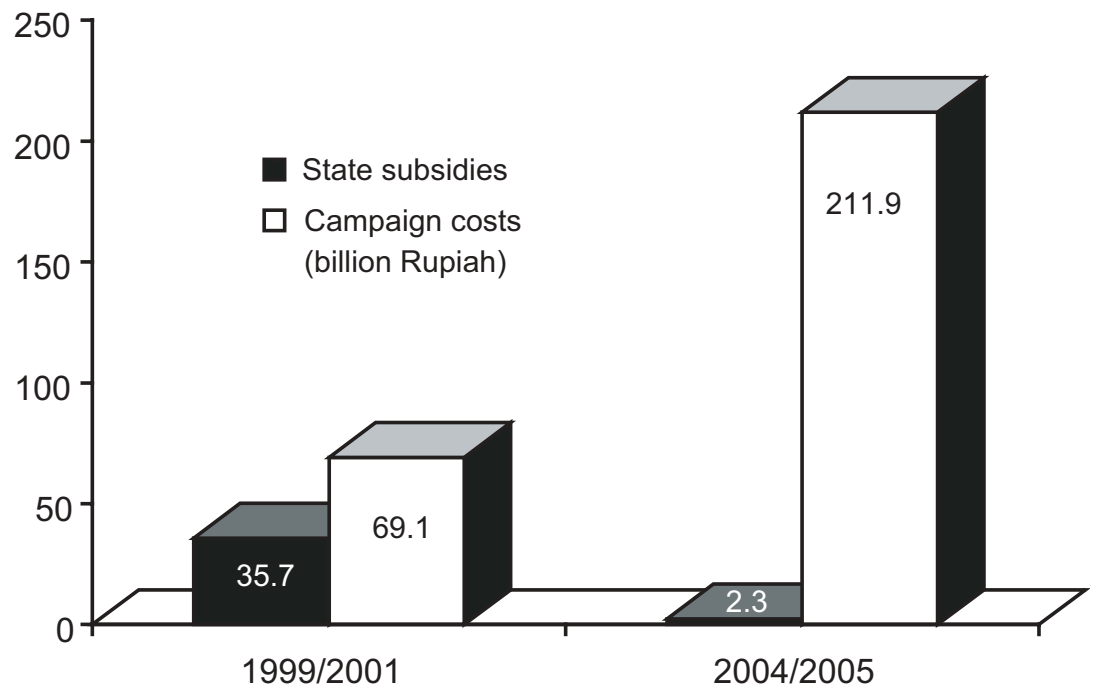

Figure 2. PDI-P's state subsidies and campaign costs, 1999-2005.

Note: Figures show PDI-P's annual revenues based on the 2001 and 2005 presidential decrees on public party financing, and PDI-P's auditing reports for the 1999 and 2004 elections respectively.

revenues was accompanied by significant increases in the cost of political activity. In 1999, only one parliamentary election had been held, while the presidential ballot was still conducted in the MPR [Majelis Permusyawaratan Rakyat, People's Consultative Council]. By contrast, the year 2004 witnessed no less than three elections, with one parliamentary and two rounds of presidential polls stretching the parties' budgets. In addition, from 2005 onwards, governors, mayors and district heads were directly elected by the people. In consequence, the expenditure of political parties grew exponentially. In 1999, PDI-P had reported campaign expenses of 69.1 billion Rupiah; in 2004, this figure rose to 211.9 billion. Certainly, these were only the officially acknowledged costs, and did not include the expenditure by individual candidates and party functionaries. With state subsidies declining and political costs rising (see Figure 2), the parties came under increased pressure to raise additional funds, both internally and externally.

The need for accelerated fund-raising efforts had an immediate impact on the parties' representatives in the legislatures. Prior to 2005, members of parliament had typically handed around 10 to $20 \%$ of their 
salaries to the central boards of their parties, but after the state subsidies were cut, some party leaders requested up to $40 \%$. Moreover, legislators were increasingly asked to cover the costs of party events and financially maintain the branch offices in the area in which they were nominated. Not surprisingly, the parliamentarians responded to these increasing financial demands from their parties by intensifying their own fund-raising activities. First and foremost, they requested a substantial salary increase from the state, which was granted in late 2005 . The monthly salary and allowance package for national legislators increased by $82 \%$ to around 50 million Rupiah (US\$5,555), and local members of parliament received similar rises in the following year. ${ }^{35}$ In addition, parliamentarians continued to expand their fundraising efforts from external sources: they received money from donors who had particular interests in the passing of certain pieces of legislation, accepted payments from government departments that wanted their budgets approved, and took money from candidates for executive and judicial positions for which the parliament had appointment or confirmation authority. Numerous examples of such practices surfaced in the press, with the most recently revealed case involving the payment of 16.5 billion Rupiah by the central bank to 16 parliamentarians in order to secure the passing of the Banking Act. ${ }^{36}$

While the legislatures were important sources of fund-raising for the parties and their representatives, the executive institutions were equally crucial in this regard. Parties sought participation in government in order to gain access to key ministries and other agencies with significant patronage potential. All Indonesian governments since 1999 have been multi-party coalitions, with almost every major party represented in cabinet. Accordingly, most parties had control over at least one ministry at any given time, which was sufficient to mobilize resources for their supporters or cadres. Ministers are expected to make contributions to the party coffers, hire functionaries for influential bureaucratic jobs, make the infrastructure of their departments available for party events and recruitment efforts, and help the party with its electoral preparations. However, these patronage relationships between ministers and their parties are not always exercised through corruption and nepotism - more often than not, they are organized through official government programmes. In November 2007, the Chairman of PPP, Suryadhama Ali, who is also Minister for Cooperatives and Small

35 'House of Reps: just who are they representing?' Jakarta Post, 23 July 2005.

36 'Anwar Sebut Nama Pejabat BI', Jawa Pos, 27 November 2007. 
Enterprises in Yudhoyono's cabinet, announced that his department would channel 1.6 trillion Rupiah (US\$178 million) in credits to smallscale businesses affiliated with the Muslim organizations NU and Muhammadiyah. ${ }^{37} \mathrm{NU}$ and Muhammadiyah voters form the core of PPP's constituency, and Suryadhama himself was an NU leader before joining PPP. Obviously, other ministers launched similar programmes for their own constituencies, using state money to attract additional cadres for their parties.

\section{The commercialization of party politics}

Another important consequence of the growing financial needs of the political parties was the increasing dominance of entrepreneurs over party boards and their policies. In some cases, businessmen operated from behind the scenes to exert influence through their donations, but others assumed more direct control over parties. In 2005, the almost unknown textile entrepreneur Sutrisno Bachir became chairman of PAN [Partai Amanat Nasional, National Mandate Party], a modernist Muslim party previously headed by Amien Rais. In the competition for the party leadership, he had beaten another oligarch, former Finance Minister Fuad Bawazier. In Golkar, the entrepreneur and Vice-President Jusuf Kalla had himself been elected party chairman in late 2004, and his fellow businessman Abdurizal Bakrie took up senior positions both in the party and in cabinet. This trend was evident across the party spectrum, and significantly changed the socioeconomic fabric of party politics. In his research on the subject, Bima Arya Sugiarto has demonstrated that $39.8 \%$ of all members of the 2004 national parliament were entrepreneurs, a substantial increase compared with $1999 .{ }^{38}$ In the PAN faction, the percentage of entrepreneurs had even doubled to more than $60 \%$. Evidently, many aspiring party officials understood that in order to cover the increasing costs of political operations, they needed to be independently affluent. For example, Maruarar Sirait, a young PDI-P politician, explained that 'I decided to go into business for five years before becoming a politician - without my own money, I wouldn't be able to pay for my political activities'. ${ }^{39}$

This growing commercialization of party politics was particularly visible in the local elections for governors, mayors and district heads. From June 2005 onwards, these positions were determined through direct 
popular ballots, replacing the previous indirect elections held in local legislatures. Political parties still nominated the candidates for the direct polls, but given their financial constraints, party boards often found it impossible to finance the campaigns of their own cadres. In consequence, most parties decided to offer the nominations to affluent non-party figures, including bureaucrats, entrepreneurs and retired security officers. ${ }^{40}$ In exchange for the nomination, candidates were expected to pay a hefty fee to the party and its individual functionaries, and promise political and financial patronage if elected to office. In reality, however, successful non-party candidates rarely cultivated close ties to the party that had nominated them, insisting that the fee they had paid was sufficient compensation for the services rendered by the party during the election campaign. With parties increasingly marginalized from local government, politico-economic donors began to direct their contributions to individual candidates rather than the major parties. As Golkar's Deputy Treasurer Airlangga Hartarto complained in 2006, 'after the introduction of direct elections, the investors no longer come to us, they go directly to the candidate - they believe spending money on parties is a waste of their time and resources'. ${ }^{41}$ In other words, the parties were caught in a vicious circle: their financial weakness forced them to raise money by selling key positions in local government to external power brokers, but the consequential decline in the parties' political relevance further undercut their ability to attract regular contributions from sponsors.

It is important to note that only very few party politicians proposed to solve this dilemma by returning to the high levels of public party financing that existed before 2005. While the new law on political parties, which was passed in December 2007, reinstated the vote-based funding formula, legislators left it to the government to determine the extent of state subsidies. ${ }^{42}$ In the deliberations for the bill, party leaders showed more interest in the inclusion of a clause that would have allowed them to establish party-owned companies. Although the idea was ultimately rejected, it showed the ambiguous attitude of party politicians towards public funding on the one hand and self-generated

40 Michael Buehler and Paige Tan (2007), 'Party-candidate relationships in Indonesian local politics: a case study of the 2005 regional elections in Gowa, South Sulawesi province', Indonesia, Vol 84, pp 41-69.

41 Interview with Airlangga Hartarto, 30 October 2006, Jakarta.

42 Communication with Ganjar Pranowo, Member of Parliament for PDI-P and head of the parliamentary committee for the deliberation of the bill on political parties, 30 November 2007, Jakarta. 
revenues on the other. Apparently, party leaders are aware that proposing the reintroduction of substantial state subsidies would require them to commit to strict transparency and accounting standards, which Indonesian politicians naturally find not very attractive. In 2004, only 13 out of the 24 parties participating in the elections handed in their auditing reports, with a mere four of these submitted on time and only one conforming to the required standards. ${ }^{43}$ It seems that party leaders, despite the severe financial shortfalls created by the cut in state subsidies in 2005 , prefer to raise their own funds through political patronage, commercial activities and external donations. While this approach forces parties to compete for contributions and the support of financial patrons, it allows them to control their own budgets without having to explain their expenditures to the state, the media and civil society. Given this preference, the commercialization of Indonesian party politics is likely to intensify ahead of the 2009 elections.

\section{The bureaucracy: 'tactical' funds, corruption and institutional autonomy}

In order to function properly, democracies need effective and accountable bureaucracies to implement the policies decided upon by executive and legislative leaders. If bureaucracies change, sabotage or subvert the decisions made by democratically legitimized representatives of the state, even polities with strong electoral and executive frameworks will find it difficult to translate policy into concrete political action. ${ }^{44}$ In this context, self-funding bureaucracies are particularly dangerous for the development of stable and transparent democratic systems. Bureaucracies that are able to collect and control their own budgets are much more likely to undermine political decision-making processes than those that depend on strictly supervised state allocations. This problem is of great significance in transitional states, where new democratic governments often have to work with bureaucracies from previous authoritarian regimes. Equipped with their own money and drawing from still-functioning patronage relationships with political institutions,

43 International Foundation for Electoral Systems (2004), 'Campaign finance, regulation and public disclosure in the Republic of Indonesia: reporting and public disclosure of financial activity of political parties and electoral participants', November, Jakarta, p 11.

44 Edward Page (1992), Political Authority and Bureaucratic Power, 2 ed, Harvester Wheatsheaf, New York et al, p 174. 
security forces and businesses, such bureaucracies can easily obstruct the democratic transition - and sometimes even cause it to collapse.

The bureaucracy in Indonesia has often played a decisive role in the downfall or maintenance of political regimes. In the 1950s, political parties utilized the bureaucracy to channel state funds to their cadres and constituencies. Bureaucrats affiliated with parties piled up huge off-budget funds, which they subsequently disbursed to their party boards or used to finance their increasingly luxurious lifestyles. The impression of rampant corruption in the bureaucracy and the parties contributed significantly to the decline of parliamentary democracy, and delivered welcome arguments to the military and President Sukarno to justify their authoritarian takeover in $1959 .{ }^{45}$ Under Suharto's New Order, the bureaucracy was a major tool of regime maintenance, imposing a tight system of social control, political scrutiny and organizational conformity. However, even under Suharto's watch, the bureaucracy was encouraged to set aside large funds to finance operations that the regime did not want to see exposed. These included payments to Golkar for its electoral campaigns, to the armed forces for their operations against regime dissidents, and to Suharto's cronies and family members for their foundations and businesses. ${ }^{46}$ Thus when Suharto fell in 1998, the Indonesian bureaucracy was already well entrenched in the practice of collecting off-budget monies and using them for activities that neither the control bodies of the state nor the media were supposed to notice.

\section{Off-budget funds in the bureaucracy after 1998}

The democratization and deregulation of Indonesia's political system after 1998 confronted the bureaucracy with a completely new set of challenges. The centralist regime that had held the bureaucracy together had disappeared, making way for a polity largely dominated by political parties, entrepreneurs and influential socio-religious leaders. This diversification of political power convinced the bureaucracy that controlling independent sources of revenue was more important than ever. Fearing that newly emerging political forces would reduce their powers and privileges, senior bureaucrats assembled sizeable war chests for a number of purposes. To begin with, leading bureaucrats set up 'tactical

45 Herbert Feith (1962), The Decline of Constitutional Democracy in Indonesia, Cornell University Press, Ithaca, New York, p 463.

46 Adam Schwarz (2004), A Nation in Waiting, Talisman, Singapore, pp 157-161. 
funds' [dana taktis], which could be mobilized to fund operational costs independently from the state's financial control authorities. ${ }^{47}$ Through this mechanism, bureaucracies avoided long-winded negotiations with parliament over budget allocations, were able to spend money faster than would usually be the case, and escaped difficult and legally risky auditing processes. Second, the money was used to pay off politicians who might otherwise show an unwelcome interest in the budgetary affairs of government departments and other agencies. These payments went mainly to members of parliament who were in charge of supervising and approving state allocations for the various ministries. For instance, bureaucrats in the Department of Energy and Natural Resources would 'cultivate' members of Commission VII, which was tasked with controlling this ministry, while the Department of Religious Affairs would make sure that members of Commission VIII received contributions, and so forth. ${ }^{48}$

Moreover, some bureaucrats formed deliberate alliances with key parties, paying them regular allowances in exchange for political protection. Hoping that their political connections would translate into promotions to better positions and less scrutiny of their monetary affairs, senior bureaucrats typically aligned themselves with the strongest parties in government. In addition, the bureaucracy used its independently raised funds to secure the passing of certain pieces of legislation in parliament - the drafts for which they had often written themselves. The case of the central bank cited above was only the most recent in a long series of similar incidents, with most ministries paying for laws that were beneficial to them. Finally, many bureaucrats also collected funds to prepare their own political careers $-36 \%$ of all candidates for local government positions in the direct elections after 2005 were state bureaucrats, the largest such group of nominees. ${ }^{49}$ The money they had

47 Inbrahim Fahmy Badoh (2007), 'Skandal Dana Taktis Departemen', Koran Tempo, 5 May 2007.

48 These payments by the bureaucracy to parliamentarians came in many different forms: for instance, cash payments in envelopes handed out during hearings or visits to departments; gifts for special occasions such as weddings or the Muslim fasting month; provision of travel allowances; invitations to undergo the Muslim pilgrimage; scholarships for parliamentarians' children; contributions to Muslim boarding schools or charitable organizations run by parliamentarians; and offers to build or repair their houses. See 'Haji “Abidin” Dilaporkan ke Mendagri', Wawasan, 17 November 2007; 'Percikan Kecil di Komisi XI', Suara Merdeka, 28 September 2002; 'Korupsi, Parsel dan Panjang Usia', Pikiran Rakyat, 31 October 2006; 'Abdullah Zaini Akui Terima Dana Taktis KPU', Suara Merdeka, 16 June 2005. Marcus Mietzner (2005), 'Local democracy', Inside Indonesia, Vol 85, pp 17-18. 
obtained during their long bureaucratic careers was used to compensate political parties for nominating them, build up effective electoral machines, and win the support of local parliaments when elected to office. Overall, the bureaucracy used its off-budget funds to strengthen its position vis-à-vis other political forces - by forging alliances with key parties, fending off investigations into its organizational affairs, engineering the enactment of favourable regulations, and seeking positions of political leadership for some of its senior representatives.

The wide variety of activities and operations covered by off-budget funds in the bureaucracy was reflected in the large number of illicit bank accounts in government departments and agencies. Each year, the Supreme Auditing Board [BPK, Badan Pemeriksaan Keuangan] examines the accounts of ministries and other executive offices held in state and private banks, and subsequently announces the number of those accounts that do not conform to administrative standards. These are typically accounts held in the name of senior bureaucrats, rather than in the name of the institution. In May 2007, the BPK revealed that it had discovered 5,241 such accounts, which contained a total of 9.08 trillion Rupiah (US\$1 billion). The Department of Religion had 92 accounts with 3.82 trillion Rupiah in them, followed by the Department of Defence with 1.83 trillion Rupiah in 136 accounts and the Ministry of Finance with 1.12 trillion Rupiah in 260 accounts (see Figure 3). ${ }^{50}$ While President Yudhoyono instructed his finance minister to ensure that these accounts were closed, and some have been dissolved since then, the BPK tends to find thousands of new accounts each year. Apparently, many officials simply shift the money from one account to another, or transfer the funds from state to private banks. This suspicion was confirmed by the government's Centre for the Registration and Analysis of Financial Transactions [PPATK, Pusat Pelaporan dan Analisis Transaksi Keuangan], which is in charge of screening all financial transactions for indications of money laundering. The PPATK stated in 2007 that many bureaucrats used illicit accounts to hide their private wealth, trying to evade state prosecutors who had begun to investigate their personal bank accounts for traces of corruption. ${ }^{51}$ The PPATK also indicated that, out of 10,000 suspicious transactions, less than $10 \%$ had been followed up by law enforcement agencies.

While most cases of illicit fund-raising and corruption in the 


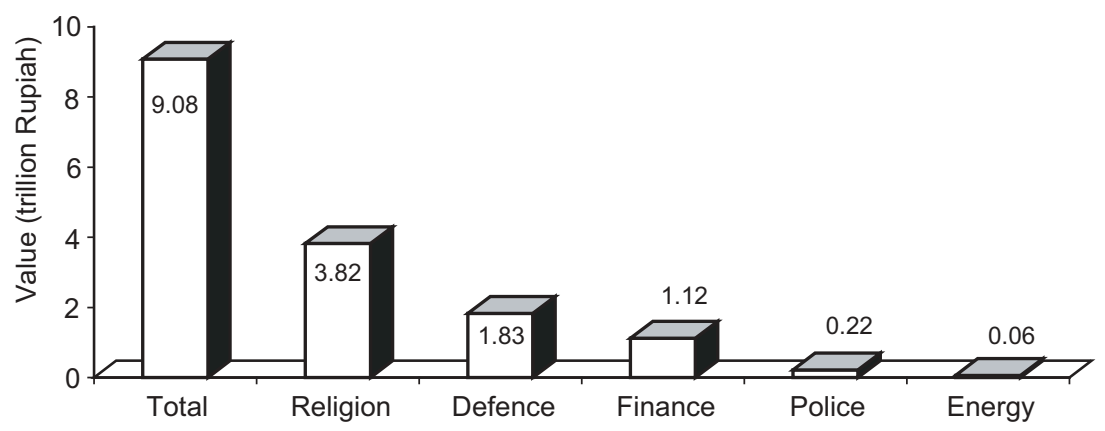

Figure 3. Off-budget accounts in Indonesian ministries and agencies (2007). Source: Figures provided by Badan Pemeriksaan Keuangan (BPK, the Supreme Auditing Board).

bureaucracy remained without legal consequences for the perpetrators, some were brought before the courts. Especially since the creation of the Anti-Corruption Commission [KPK, Komisi Pemberantasan Korupsi] in 2003 and the inauguration of Yudhoyono as president in 2004, the number of investigations and trials against corrupt officials has increased significantly. However, as the BPK and PPATK figures cited above suggest, this increase in the frequency of indictments and convictions has not yet led to a decline in illegal financial transactions in government departments. It appears that the temptation to raise funds outside of official channels remains high, with the prospect of obtaining personal affluence and political influence still luring many bureaucrats into such practices. This tempting opportunity to combine private enrichment with financial politicking became evident in the case of Rokhmin Dahuri, the Minister for Maritime Affairs and Fishery under the Megawati government between 2001 and 2004. His prosecution and eventual conviction offers fascinating insights into the internal machinations and motivations of political fund-raising in the post-Suharto bureaucracy.

\section{Case study: the rise and fall of Rokhmin Dahuri}

Rokhmin's case reflected general patterns of fund-raising and corruption in the bureaucracy, and was therefore in no way exceptional. The only difference from the myriad of other cases was that some of Rokhmin's subordinates judiciously noted all off-budget revenues and expenditures in their books, which the prosecutors subsequently used to bring the 
former minister to trial. From these books, a clear picture of Rokhmin's money-collecting practices emerged: internally, he required all agencies in his department, including the ministry's branches in the regions, to set $1 \%$ of their allocations aside for his off-budget fund. The money was managed by Rokhmin's assistants and made available to their minister at his discretion. In addition to the funds raised within the department, Rokhmin received 'donations' from businessmen and bankers who had economic interests in cooperating with his department. In one such case, Rokhmin was given 400,000 Singapore dollars in cash from an interested entrepreneur in exchange for favourable treatment by the ministry. The heads of two government-owned banks gave him 100 million Rupiah each, and while they stated that these were contributions to Rokhmin's alleged charity fund, it seems to be evident that they too hoped to advance their business interests by gaining exclusive access to the minister. Overall, Rokhmin collected at least 11.395 billion Rupiah (US\$1.3 million) through such practices. While other estimates went as high as 30 billion Rupiah, the prosecutors indicted him only on the above-mentioned figure, to which witnesses were prepared to testify. ${ }^{52}$

The documentation of Rokhmin's expenditure was as illuminating as that of his revenue flows. There were five different fields towards which Rokhmin directed his illicitly collected funds. To begin with, he accessed the money to cover many of the operational expenses incurred by his ministerial activities, ranging from travel expenditure to representation costs and salaries for assistants. This allowed him to circumvent government restrictions on travel expenses and - particularly - on hiring expert staff, which usually force ministers to pick candidates from a pool of bureaucratically experienced administrators. Second, Rokhmin bought gifts for and gave financial contributions to influential politicians. These included expensive batik shirts for the president and campaign donations to her political opponents, such as Amien Rais and Wiranto. As an academic with no power base in a political party, Rokhmin apparently felt compelled to target the whole political spectrum with his payments. Members of parliament from all parties, presidential candidates and leaders of Muslim organizations (according to Rokhmin, a total of 1,700 people) received 'envelopes' containing sums between 10 and several hundred million Rupiah. ${ }^{53}$ Even a member of the PKS [Partai Keadilan Sejahtera, Prosperous Justice Party] - a

52 'Rokhmin Dituntut 6 Tahun, Nelayan Protes', Harian Sinar Indonesia Baru, 28 June 2007.

53 'Rokhmin Tolak Dianggap Merugikan Negara', Kompas, 4 July 2007. 
puritanical Islamic party with a reputation for being strictly against corrupt practices -had to admit that he had received 200 million Rupiah from the minister. In his rather clumsy and inconsistent defence, the PKS politician variously claimed that a non-governmental organization under his coordination had been sent the money without his knowledge, or that he had obtained it as salary for helping Rokhmin to write his doctoral dissertation. ${ }^{54}$

The third field for which Rokhmin mobilized his off-budget funds involved more conventional forms of corruption. Obviously undeterred by the growing public scrutiny of nepotistic behaviour of government officials, Rokhmin unashamedly channelled money to his wife and relatives. While claiming that the payments to his wife were compensation for an earlier 'credit' she had extended to the ministry, and that his relatives had requested the funds to run development projects in fishing communities, the prosecutors and judges were not convinced. Most importantly, the transfers to his family undermined Rokhmin's argument that he had not personally profited from his off-budget funds, but had only used them in the interests of the ministry. The fourth target of Rokhmin's illicit expenditures were institutions that could decide over policies and regulations that were of crucial importance to his department. In the most prominent of such cases, Rokhmin made payments to a parliamentary committee deliberating the new fishery bill, trying to secure the passing of clauses that strengthened the role of the ministry. In his testimony during the trial, Rokhmin claimed that 5.3 billion Rupiah of his funds went into this effort. ${ }^{55}$ Finally, he funded charitable and other social events, and while these donations may indeed have helped poor communities to overcome economic hardship, they also consolidated his position as a powerful financial and politico-bureaucratic patron. The impact of these payments became visible during Rokhmin's trial, when recipients of the funds - mostly fishermen and Muslim activists - staged demonstrations in his defence.

The analysis of Rokhmin Dahuri's case has highlighted some important features of political fund-raising and corruption in the post-authoritarian polity. While personal enrichment was definitely a critical element in this endeavour, and was cited by the judges as the main reason for Rokhmin's conviction and sentencing to seven years in prison, it was only one of the factors. Equally important were his motivation to build 
patronage networks with political parties, parliament and the government, and his intention to shield his department from external scrutiny and intervention. Much of his illicitly raised money went into paying off politicians who otherwise could have interfered in the ministry's internal affairs, and particularly those members of parliament who deliberated the new bill on fishery. Securing favourable regulatory frameworks for the department was one of Rokhmin's major considerations, and his successors undoubtedly benefited from this. Given the potentially high rewards of off-budget fund-raising, it is likely that Rokhmin's example will continue to be the rule rather than the exception for years to come.

\section{Conclusion}

The discussion of illicit fund-raising practices in Indonesia's military, political parties and bureaucracy since 1998 has pointed to a number of joint features and patterns. Most importantly, while personal enrichment plays a significant role in the self-financing mechanisms in all three sectors, their inherent drive for institutional autonomy is an equally crucial factor. In the military, senior generals have collected huge off-budget funds partly in order to support their extravagant lifestyles, but also to remain independent from civilian control authorities of the state. Believing that civilians are self-absorbed and incompetent, military leaders have since the mid-1940s striven to be financially autonomous. This autarchy has allowed them to run operations without having to beg parliament and the government for budget allocations, and has enabled the generals to maintain the military's institutional strength despite significant cuts to its political privileges since 1998. As demonstrated above, after Suharto's fall, several attempts to reform the army's territorial structure - the main tool for fund-raising in the regions - were unsuccessful, and the government's plans to take over military-owned businesses by 2009 were marred by indecisiveness, unclear definitions and organizational delays. According to estimates by the Minister of Defence, $30 \%$ of all military expenditures are still raised through off-budget mechanisms, and while this figure is down from $70 \%$ in the early post-authoritarian transition, it remains an intolerably high percentage of the total defence budget. Militaries that raise substantial proportions of their budget by themselves pose a latent threat to democratizing states, and given its long history of military interference in politics, Indonesia must certainly exercise particular caution in this regard.

Similar to the military, the fund-raising activities of party politicians 
were driven by their strong interest in obtaining both personal affluence and institutional autonomy from the state. Since the dramatic cut in state subsidies to political parties in 2005, party leaders have intensified their efforts to raise funds from their representatives in the legislatures, extort contributions from independent candidates for local government office, collect external donations from entrepreneurs and force party members in government to channel funds to the party coffers. In 2001, the party leadership of PDI-P was still able to cover $51.6 \%$ of its 1999 campaign expenses with the state subsidies it received in that year. In 2005, PDI-P could only pay for around $1 \%$ of its 2004 campaign costs with monies derived from public party funding. In consequence, $99 \%$ was raised through some of the methods mentioned above, increasing the political corruption in executive and legislative institutions, and distracting parties from carrying out their core functions of political representation and aggregation. Despite these negative side effects, however, parties appear to prefer a system of self-funding to a tightly controlled regime of public party financing. While illicit fund-raising is a risky and exhausting enterprise, it enables parties to allocate monies for any purpose they see fit, including personal patronage, bribery, smear campaigns against opponents, and so forth. Public party funding, by contrast, would be attached to publicly scrutinized auditing requirements, to which none of the parties seems particularly keen to adhere. Accordingly, the chairman of PKB [Partai Kebangkitan Bangsa, National Awakening Party], the largest traditionalist Muslim party, commented in December 2007 that all public funding for parties should be discontinued by $2014 .^{56}$

Illicit fund-raising in the bureaucracy was motivated by comparable considerations. While bureaucrats enriched themselves and their families, one of the main factors in their efforts was to maintain the financial and institutional autonomy of their departments, agencies and offices vis-à-vis the government and other political actors. ${ }^{57}$ Consequently, the

‘2009, Partai Masih Mendapat Subsidi', Jawa Pos, 2 December 2009.

The present discussion of illicit fund-raising in the Indonesian military, political parties and bureaucracy challenges the conventional definition of corruption as the misuse of public office for private gain. In all three cases, most of the illicitly raised funds flowed back into operations aimed at strengthening certain institutions or the position of individual leaders within them. While it could be argued that the efforts of elites to defend and empower their institutions are in themselves designed to increase their ability to extort even more money from the state, the fact that so much of the illicit funding was used for institutional activity suggests that institution-building played a significant role in the motivations of the perpetrators. 
bulk of the illegally raised funds went into operations that aimed to secure the goodwill of parliamentarians, executive controllers or other agencies tasked with supervising the bureaucracy and its senior officials. The case of Rokhmin Daruri has shown that buying off politicians, giving gifts to superiors, engineering favourable pieces of legislation and building up patronage networks with potentially useful civil society groups absorbed much of the monies collected within the bureaucracy and from external donors. Most importantly, the findings of the BPK and the PPATK, which identified more than 5,000 illegal accounts containing around US\$1 billion, suggest that this pattern of illicit fund-raising and political patronage is spread throughout the bureaucracy; and, as in the case of the political parties and the military, there appear to be few bureaucrats who demand that the state should provide more official funds to cover the budgetary shortcomings within its administrative apparatus. In fact, there were numerous cases in which bureaucracies - particularly at the local level - preferred to park state funds in banks instead of using them to modernize the administration or invest in infrastructure. In 2007, the government announced that local administrations had stored more than 90 trillion Rupiah, or US\$10 billion, in the banks, mainly by buying certificates from the central bank [SBI, Sertifikat Bank Indonesia].$^{58}$ Evidently, shortage of money is an insufficient reason to explain and justify the raising of off-budget funds in the bureaucracy.

The fund-raising activities in the military, the political parties and the bureaucracy have seriously impacted on the professionalism, accountability and internal coherence of these three key actors in Indonesian governance. In the military, the engagement of senior officers and field troops in collecting monies has not only distracted them from their core defence and security functions, but has brought them into open conflict with the law. Backing prostitution venues and gambling dens, extorting money from business owners and renting out military land to private investors obviously runs counter to the image of a modern and transparent military. In addition, the availability of independent funds has undermined the legal and political accountability of the armed forces vis-à-vis civilian control institutions. Equipped with their own operational funds, the armed forces find it easy to ignore, obstruct or sabotage the directives of the civilian political leadership. The events in East Timor in 1999 and during the breakdown of the "cessation of hostility 
agreement' for Aceh in 2003 were cases in point, but the Indonesian government does not seem to have drawn adequate conclusions from these incidents. Crucially, the practice of self-funding is not only harmful for democratic civil-military relations, but it also damages the institutional coherence of the military itself. With individual units in charge of their own finances, local commanders have less reason to obey the instructions from their headquarters. In Indonesia, the central command has tried to minimize the effects of this phenomenon by rotating local officers more frequently than is the case in other countries; however, the armed forces leadership has yet to acknowledge that bringing its budget online could positively impact on the military's internal solidity and would thus be in its own interest.

As with the military, political parties have increasingly engaged in raising external funds, particularly since the cut in state subsidies in 2005. This has negatively affected their ability to act as vehicles of political reform, with parties now forced to sell off nominations for executive and legislative office to external bidders, fulfil the requests of economically interested patrons and allow entrepreneurs to assume greater roles in party management. Besides increasing the dependence of parties on donors and undermining their democratic functions, the practice of collecting illicit party funds has also loosened the control of central party boards over their branches. As in the TNI, financially self-sufficient party branches feel confident to launch their own political initiatives, making it impossible for parties to present themselves as consistent and predictable entities. In the bureaucracy, finally, the collection of off-budget funds allowed senior administrators to operate independently from other state institutions (and, ironically, from their own central government), eroding the role of the bureaucracy as a loyal and coherent executor of policy decisions made by the democratically elected leadership. In short, the practice of off-budget funding points to continued serious defects in Indonesia's democratic system, turning the country into what Larry Diamond and Leonardo Morlino called a 'low-quality democracy', in which open and fair elections take place, but a host of institutional problems persist. ${ }^{59}$ Accordingly, if Indonesia wants to move to the next stage in its process of democratic consolidation, it urgently needs to improve the financial control of its main political and security institutions.

59 Larry Diamond and Leonardo Morlino (2004), The Quality of Democracy, Working Paper Number 20, Center on Democracy, Development, and the Rule of Law, Stanford Institute for International Studies, Stanford, CA. 